\title{
Chemist expected to head UK medical research council
}

\section{London}

David (Dai) Rees seems set to succeed Sir James Gowans as secretary of the UK Medical Research Council (MRC). When the council meets on 5 February, it is expected formally to recommend the appointment to the Secretary of State for Education and Science, Kenneth Baker.

A chemist by training, 50-year-old Rees spent 14 years after graduating in academic life before joining Unilever Research in Colworth, Bedfordshire, in 1970. In 1980 , while chairman of the Science Policy Group for Unilver, he became associate director of the MRC Cell Biophysics Unit, spending one day a week assisting the director. Two years later, Rees left Unilever to become director of the MRC's National Institute for Medical Research at Mill Hill, London.

In his four years there, Rees has organized the many separate laboratories within the institute into four groups,

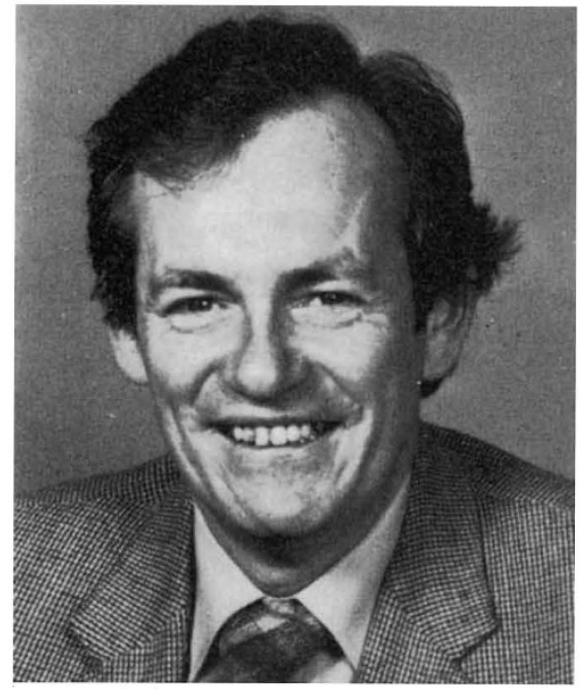

From carbohydrate research to MRC secretary? bringing in Peter Rigby to head one of them and to try and infuse the whole institute with modern biological methodology. $\mathrm{He}$ has also initiated a Centre for $\mathrm{Col}-$ laborative Research, of which he is acting head, dedicated to joint projects between MRC and UK-based industry. Glaxo, Wellcome, Thorn-EMI and Amersham are among the first companies to have made use of the centre.

Although more protected than most of the research councils from the government's cuts in public spending, MRC is still cash-starved and will need more industrial funds if it is to protect its own establishments, let alone expand. From that point of view, Rees's experience and continued contacts with industry have always made him a strong contender to take over the council since Gowans announced his intention to leave. That, plus his repu- tation as a good manager, seem to have been enough to outweigh the fact that Rees, unlike some other strong contenders for the job, has no medical qualifications. His own research has veered from carbohydrate chemistry towards the chemistry and biology of cell surface interactions.

Peter Newmark - A year after endorsing the idea of a merger between the two major UK centres for clinical research, MRC has appointed a firm of management consultants to help decide how to proceed. The firm of Deloitte Haskins and Sells has until May to report to the Clinical Research Coordinating Committee of the council, chaired by Sir Robin Nicholson. Among its tasks is to decide which of the two existing centres, the council's Clinical Research Centre at Northwick Park or the Royal Postgraduate Medical School in Hammersmith, both in London, should absorb the other to form a cost-effective multispeciality centre of postgraduate medical research and education.

\section{Electronic SOS to Gorbachev shows Soviets softening on refusniks?}

\section{Rehovot}

THE Soviets seem to be changing their public response to refusnik pressure. The participants in last week's meeting of the International Federation of Scientists for Soviet refusniks in Vienna expected and received support from the western delegations at the European Security Conference but surprisingly, the Soviets also accepted. They made no attempt to claim the pressure exerted on behalf of the refusniks was "interference in Soviet internal affairs".

Weizmann Institute physicist Harry Lipkin, a member of the Israeli group in Vienna, is still not sure whether "it reflects a real change in policy or the fact that Mikhail Gorbachev understands, and practises, western-style public relations". Meanwhile, in any case, Lipkin and his colleagues are determined to continue putting pressure on the Soviets, using their status and connections as scientists.

A couple of weeks ago, Soviet immigrant scientists in Jerusalem received a call for help from Alexander Ioffe, an eminent refusnik mathematician in Moscow, who had gone on hunger strike to protest at the Soviet authorities' refusal to allow his son's family to leave for Israel after earlier refusing a similar request from Ioffe himself (see Nature 325, 289; 1987). Ioffe asked that appeals on his behalf go to Gorbachev, Professor Guri Ivanovich Marchuk, president of the Soviet Academy of Sciences and Professor Ludvig Dimitrievich Fadeev, a Leningrad scholar who is president of the International Union of Mathematicians. Ioffe's message was translated into English by his friends in Jerusalem and transmitted by telephone to Lipkin in Rehovot, who then sent it via his computer by electronic mail to friends and colleagues around the world. They, in turn, cabled Gorbachev, Marchuk and Fadeev. Within 48 hours of Ioffe's call from Moscow, Soviet officials were being petitioned on his behalf by scores of leading scientists and scientific bodies in the western world.

Ioffe ended his hunger strike when he was promised that his son's emigration request would be given favourable consideration and that his own request would also be reconsidered.

Weizmann Institute biophysicist Edward Trifonov was reunited with Professor Nikolai Bochkov of the USSR Academy of Medical Sciences on the Rehovot campus. Trifonov had begun his scientific career in Moscow and had once served on academic committees with Bochkov, who had come to Israel as a representative of his country's 'peace movement'.

Like Lipkin, Trifonov sees some positive changes in Soviet policies, including

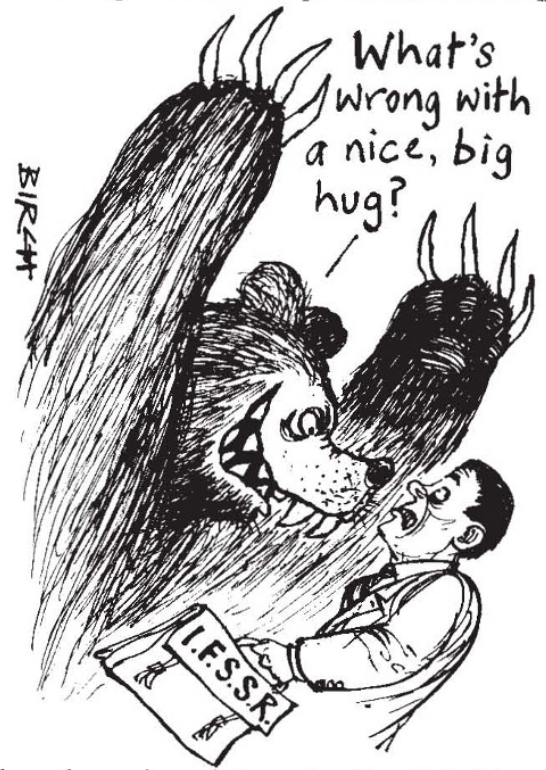

the release from internal exile of his friend and mentor Andrei Sakharov (with whom Lipkin also has close ties). But knowing his Russian history, Trifonov is afraid that, as in the past, a period of democratization will be followed by a period of repression.

"So while Gorbachev may have good intentions", Trifonov concludes, "I don't trust the system". Nechemia Meyers 